\title{
Potential Use of Rice Husk Ash for Enhancing Growth of Maize (Zea mays)
}

\author{
P. Saranya, C.M. Sri Gayathiri and K.M. Sellamuthu*
}

Department of Soil Science and Agricultural Chemistry, Directorate of Natural resource Management, Tamil Nadu Agricultural University, Coimbatore-641003, Tamil Nadu, India

\author{
*Corresponding author
}

\begin{tabular}{|l|}
\hline Key w or d s \\
Rice husk ash, \\
Maize growth \\
\hline Article Info \\
\hline $\begin{array}{l}\text { Accepted: } \\
\text { 10 February } 2018 \\
\text { Available Online: } \\
\text { 10 March } 2018\end{array}$ \\
\hline
\end{tabular}

\section{Introduction}

Rice husk ash produced industrially during combustion of rice husk for various purposes such as power generation is a mixture of ash, charred hull and fresh rice husk at different proportions. It is light in weight, has low bulk density, increases the soil $\mathrm{pH}$, improves the aeration in the crop root zone and also increases the water holding capacity and level of exchangeable potassium and magnesium (AICOAF, 2001). Annually, for an average production of 120 million tonnes of paddy, about 24 million tonnes of the husk is produced during milling. This generates about
4.4 million tonnes of rice husk ash (RHA) (15\% of rice husk) annually (Gonçalves and Bergmann, 2007). This large residue volume poses a serious threat to environment with regard to waste disposal. The chemical constituents include silica, calcium, magnesium, phosphorus, potassium, sodium, iron, carbon and nitrogen. Amount of nutrients vary with the temperature and time which the husk is burnt. Priyadharshini et al., (2009) found that RHA application @ $4.5 \mathrm{t} \mathrm{ha}^{-1}$ results the high number of nodules and nodule weight and significantly higher yield in cowpea. Abukari (2014) found that combined treatment of $4 \mathrm{t} \mathrm{ha}^{-1} \mathrm{RHA}+90 \mathrm{~kg} \mathrm{~N}$ recorded 
the highest maize grain yield of $2.84 \mathrm{t} \mathrm{ha}^{-1}$ and the control, the lowest $\left(0.8 \mathrm{tha}^{-1}\right)$. The yield of maize crop with a dosage of $3 \mathrm{t} \mathrm{ha}^{-1}$ RHA was $5.75 \mathrm{t} \mathrm{ha}^{-1}$ and that of control plot was $0.34 \mathrm{t}$ ha $^{-1}$ (Nwite et al., 2011). Thind et al., (2012) recorded that application of rice husk ash at 10 $\mathrm{t} \mathrm{ha} \mathrm{h}^{-1}$ to wheat increased the grain yield of wheat by 25 percent.

Muntohar et al., (2002) found that RHA reduces the swelling potential of the soil when applied along with lime. Onwudike et al., (2015), found that RHA @ $5 \mathrm{t} \mathrm{ha}^{-1}$, the bulk density of the soil decreased from $1.44 \mathrm{~g} \mathrm{~cm}^{-3}$ to $1.39 \mathrm{~g} \mathrm{~cm}^{-3}$, whereas the total porosity and moisture content increased from $45.7 \%$ and $129.4 \mathrm{~g} \mathrm{~kg}^{-1}$ to $47.5 \%$ and $134.2 \mathrm{~g} \mathrm{~kg}^{-1}$ respectively. Application of $10 \mathrm{t} \mathrm{ha}^{-1}$ of RHA to either rice or wheat for three years supplied a total of $58 \mathrm{~kg} \mathrm{P} \mathrm{ha}^{-1}$. Application of RHA to both rice and wheat compared with their application either to wheat or rice showed greater effects in increasing the Olsen-P and $\mathrm{Pi}$ fractions in the surface soil layer (Singh et al., 2013).

\section{Materials and Methods}

$\mathrm{pH}$ and $\mathrm{EC}$ was determined at 1:5 ratio as per Jackson (1973). Bulk density, particle density and porosity were determined with cylinder method (Tan, 1998). Water soluble and $\mathrm{NH}_{4} \mathrm{Ac}$-extractable $\mathrm{Ca}, \mathrm{Mg}, \mathrm{Na}, \mathrm{K}$ were determined as per Jackson (1973). Soil available N, P and $\mathrm{K}$ were determined as per Subbiah and Asija (1956), Olsen et al., (1954) and Stanford and English (1949), respectively. Total N, P and $\mathrm{K}$ in maize plant were determined as per Humphries (1956), Jackson (1973) and Toth and Prince (1949), respectively. The experiment was conducted seven treatments viz., $\mathrm{T}_{1}$ - Absolute control, $\mathrm{T}_{2}$ $-100 \% \mathrm{NPK}, \mathrm{T}_{3}-100 \% \mathrm{NPK}+5 \mathrm{t} \mathrm{ha}^{-1}$ RHA, $\mathrm{T}_{4}-100 \% \mathrm{NP}+75 \% \mathrm{~K}+5 \mathrm{t} \mathrm{ha}^{-1} \mathrm{RHA}$, $\mathrm{T}_{5}-100 \% \mathrm{NP}+50 \% \mathrm{~K}+10 \mathrm{t} \mathrm{ha}^{-1} \mathrm{RHA}, \mathrm{T}_{6}-$ $100 \% \mathrm{NP}+25 \% \mathrm{~K}+15 \mathrm{t} \mathrm{ha}^{-1} \mathrm{RHA}$ and $\mathrm{T}_{7}-$
$100 \% \mathrm{NP}+20 \mathrm{t} \mathrm{ha}^{-1}$ RHA in three replications under Completely Randomised Design. The test crop was maize (TNAU maize hybrid CO6).

Five kilograms of soil (Brown non calcareous) was taken in a plastic pot and the treatments were imposed. Maize seeds were sown on 27.02.2017, treatments were imposed and harvested after 45 days after sowing. The parameters recorded were, leaf area and plant height during 15, 30 and 45 days after sowing, shoot weight, root weight, root length and root volume at 45 days after sowing. SPAD meter readings were recorded during 15, 30 and 45 days using Chlorophyll Meter (SPAD 502) designed by the Soil Plant Analytical Development (SPAD) section, Minolta, Japan. The Minolta SPAD-502 measures chlorophyll content as ratio of transmittance of light at wavelength of $650 \mathrm{~nm}$ and $940 \mathrm{~nm}$. Three readings were taken from each replication and the average value computed using method described by Minolta (1989).

\section{Results and Discussion}

\section{Characteristics of initial soil}

Initial soil was analysed for $\mathrm{pH}, \mathrm{EC}$, bulk density, particle density, $\mathrm{KMnO}_{4}-\mathrm{N}$, Olsen-P and $\mathrm{NH}_{4} \mathrm{Ac}-\mathrm{K}$. The $\mathrm{pH}$ of the initial soil was 6.5. Electrical Conductivity was $0.17 \mathrm{dS} \mathrm{m}^{-1}$. Bulk density and Particle density of the soil were 1.25 and $1.60 \mathrm{Mg} \mathrm{m}^{-3}$ respectively. $\mathrm{KMnO}_{4}-\mathrm{N}$, Olsen-P and $\mathrm{NH}_{4} \mathrm{Ac}-\mathrm{K}$ were 224 , 39.0 and $656 \mathrm{~kg} \mathrm{ha}^{-1}$ respectively.

$\mathrm{pH}$ and EC of RHA were found to be 8.94 and $1.08 \mathrm{dS} \mathrm{m}^{-1}$. Bulk density, particle density and porosity were found to be $0.22 \mathrm{Mg} \mathrm{m}^{-3}, 0.23$ $\mathrm{Mg} \mathrm{m}{ }^{-3}$ and $4.35 \%$ respectively. Water soluble $\mathrm{Ca}, \mathrm{Mg}, \mathrm{Na}$ and $\mathrm{K}$ were $300,60,362$ and $740 \mathrm{mg} \mathrm{kg}^{-1}$. $\mathrm{NH}_{4} \mathrm{Ac}$-extractable $\mathrm{Ca}, \mathrm{Mg}$, $\mathrm{Na}$ and $\mathrm{K}$ were 2750, 150, 333 and $2722 \mathrm{mg}$ $\mathrm{kg}^{-1}$. 


\section{Effect of RHA on plant growth parameters}

\section{Leaf Area}

The leaf area during 15 DAS varied from 35.5 and $46.4 \mathrm{~cm}^{2}$. The highest leaf area $\left(46.4 \mathrm{~cm}^{2}\right)$ was observed in the treatment with $100 \% \mathrm{NP}+$ $50 \% \mathrm{~K}+10 \mathrm{t} \mathrm{ha}^{-1}$. The treatments $\mathrm{T}_{3}-100 \%$ $\mathrm{NPK}+5 \mathrm{tha}^{-1} \mathrm{RHA}, \mathrm{T}_{4}-100 \% \mathrm{NP}+75 \% \mathrm{~K}$ $+5 \mathrm{t} \mathrm{ha}^{-1}$ RHA and $\mathrm{T}_{5}-100 \% \mathrm{NP}+50 \% \mathrm{~K}$ $+10 \mathrm{t} \mathrm{ha}^{-1}$ RHA were significantly differ from others and found to be on par. The lowest value was recorded in absolute control.

On $30^{\text {th }}$ day, the leaf area varied from 178.9 to $323.7 \mathrm{~cm}^{2}$. The maximum value $\left(323.7 \mathrm{~cm}^{2}\right)$ was observed in the treatment with $100 \%$ $\mathrm{NP}+50 \% \mathrm{~K}+10 \mathrm{t} \mathrm{ha}^{-1}$. The treatments $\mathrm{T}_{4}-$ $100 \% \mathrm{NP}+75 \% \mathrm{~K}+5 \mathrm{t} \mathrm{ha}^{-1} \mathrm{RHA}, \mathrm{T}_{5}-100 \%$ $\mathrm{NP}+50 \% \mathrm{~K}+10 \mathrm{t} \mathrm{ha}^{-1} \mathrm{RHA}$ and $\mathrm{T}_{6}-100 \%$ $\mathrm{NP}+25 \% \mathrm{~K}+15 \mathrm{t} \mathrm{ha}^{-1}$ RHA were significantly differ from others and found to be on par. The lowest value was recorded in absolute control.

The leaf area on 45 DAS varied from 221.8 and $396.0 \mathrm{~cm}^{2}$. The highest leaf area $\left(396.0 \mathrm{~cm}^{2}\right)$ was observed in the treatment with $100 \% \mathrm{NP}, 25 \% \mathrm{~K}$ and $15 \mathrm{t} \mathrm{ha}^{-1}$ RHA. The treatments $\mathrm{T}_{4}-100 \% \mathrm{NP}+75 \% \mathrm{~K}+5 \mathrm{t} \mathrm{ha}^{-1}$ RHA, $\mathrm{T}_{5}-100 \% \mathrm{NP}+50 \% \mathrm{~K}+10 \mathrm{tha}^{-1}$ RHA and $\mathrm{T}_{6}-100 \% \mathrm{NP}+25 \% \mathrm{~K}+15 \mathrm{t} \mathrm{ha}^{-1} \mathrm{RHA}$ significantly differ from others and found to be on par. The lowest value was recorded in absolute control.

The mean value of leaf area varied from 146.6 and $251.3 \mathrm{~cm}^{2}$. The maximum leaf area $\left(251.3 \mathrm{~cm}^{2}\right)$ was observed in the treatment with $100 \% \mathrm{NP}+25 \% \mathrm{~K}+15 \mathrm{t} \mathrm{ha}^{-1}$ RHA. The treatments $\mathrm{T}_{4}-100 \% \mathrm{NP}+75 \% \mathrm{~K}+5 \mathrm{t} \mathrm{ha}^{-1}$ RHA, $\mathrm{T}_{5}-100 \% \mathrm{NP}+50 \% \mathrm{~K}+10 \mathrm{t} \mathrm{ha}^{-1}$ RHA and $\mathrm{T}_{6}-100 \% \mathrm{NP}+25 \% \mathrm{~K}+15 \mathrm{t} \mathrm{ha}^{-1} \mathrm{RHA}$ significantly differ from others and found to be on par. The lowest value was recorded in absolute control.

Similar findings with application of rice husk biochar on enhancement of leaf width and leaf length of spinach was observed by Milla et al., (2013).

\section{Chlorophyll content}

The SPAD chlorophyll values on 15 DAS varied from 32.4 and 42.8. The highest chlorophyll content (42.8) was observed in the treatment with $100 \% \mathrm{NP}+20 \mathrm{t} \mathrm{ha}^{-1}$ RHA. The treatments $\mathrm{T}_{3}-100 \% \mathrm{NPK}+5 \mathrm{t} \mathrm{ha}^{-1} \mathrm{RHA}, \mathrm{T}_{4}$ $-100 \% \mathrm{NP}+75 \% \mathrm{~K}+5 \mathrm{t} \mathrm{ha}^{-1} \mathrm{RHA}, \mathrm{T}_{5}$ $100 \% \mathrm{NP}+50 \% \mathrm{~K}+10 \mathrm{tha}^{-1} \mathrm{RHA}^{-\mathrm{T}_{6}}-100 \%$ $\mathrm{NP}+25 \% \mathrm{~K}+15 \mathrm{t} \mathrm{ha}^{-1} \mathrm{RHA}$ and $\mathrm{T}_{7}-100 \%$ $\mathrm{NP}+20 \mathrm{tha}^{-1}$ RHA significantly differ from others and found to be on par. The lowest value was recorded in absolute control.

On $30^{\text {th }}$ day, the SPAD chlorophyll values varied from 36.0 to 45.5 . The maximum value (45.5) was observed in the treatment with $100 \% \mathrm{NP}+75 \% \mathrm{~K}+5 \mathrm{t} \mathrm{ha}^{-1}$ RHA. The treatments $\mathrm{T}_{3}-100 \% \mathrm{NPK}+5 \mathrm{tha}^{-1} \mathrm{RHA}$ and $\mathrm{T}_{4}-100 \% \mathrm{NP}+75 \% \mathrm{~K}+5 \mathrm{t} \mathrm{ha}^{-1}$ RHA significantly differ from others and found to be on par. The lowest value was recorded in absolute control. The SPAD chlorophyll values on 45 DAS varied from 39.4 and 48.9. The highest chlorophyll content (48.9) was observed in the treatment with $100 \% \mathrm{NP}+75 \%$ $\mathrm{K}+5 \mathrm{t} \mathrm{ha}^{-1}$ RHA. The treatments $\mathrm{T}_{3}-100 \%$ $\mathrm{NPK}+5 \mathrm{t} \mathrm{ha}^{-1}$ RHA and $\mathrm{T}_{4}-100 \% \mathrm{NP}+75 \%$ $\mathrm{K}+5 \mathrm{t} \mathrm{ha}^{-1}$ RHA significantly differ from others and found to be on par. The lowest value was recorded in absolute control (Table $1)$.

The mean value of SPAD chlorophyll values varied from 35.9 and 45.3. The maximum chlorophyll content (45.5) was observed in the treatment with $100 \% \mathrm{NP}+75 \% \mathrm{~K}+5 \mathrm{t} \mathrm{ha}^{-1}$ RHA. The treatments $\mathrm{T}_{3}-100 \% \mathrm{NPK}+5 \mathrm{t}$ $\mathrm{ha}^{-1}$ RHA, T $4-100 \% \mathrm{NP}+75 \% \mathrm{~K}+5 \mathrm{tha}^{-1}$ RHA and $\mathrm{T}_{5}-100 \% \mathrm{NP}+50 \% \mathrm{~K}+10 \mathrm{tha}^{-1}$ RHA significantly differ from others and found to be on par. 
Table.1 Effect of treatments of leaf area and SPAD chlorophyll of Maize

\begin{tabular}{|c|c|c|c|c|c|c|c|c|}
\hline \multirow[t]{2}{*}{ Treatments } & \multicolumn{4}{|c|}{ Leaf area $\left(\mathrm{cm}^{2}\right)$} & \multicolumn{4}{|c|}{ SPAD chlorophyll readings } \\
\hline & 15 DAS & 30 DAS & 45 DAS & Mean & 15 DAS & 30 DAS & 45 DAS & Mean \\
\hline $\mathrm{T}_{1}$ - Absolute control & 35.5 & 178.9 & 221.8 & 146.6 & 32.4 & 36.0 & 39.4 & 35.9 \\
\hline $\mathrm{T}_{2}-100 \% \mathrm{NPK}$ & 41.1 & 275.5 & 336.4 & 217.7 & 38.5 & 40.7 & 45.1 & 41.4 \\
\hline $\mathrm{T}_{3}-100 \% \mathrm{NPK}+5 \mathrm{tha}^{-1} \mathrm{RHA}$ & 42.1 & 283.1 & 339.7 & 221.6 & 39.5 & 43.5 & 47.5 & 43.5 \\
\hline $\mathrm{T}_{4}-100 \% \mathrm{NP}+75 \% \mathrm{~K}+5 \mathrm{th \textrm {h } ^ { - 1 } \mathrm { RHA }}$ & 43.3 & 303.1 & 369.0 & 238.5 & 41.5 & 45.5 & 48.9 & 45.3 \\
\hline $\mathrm{T}_{5}-100 \% \mathrm{NP}+50 \% \mathrm{~K}+10 \mathrm{tha}^{-1} \mathrm{RHA}$ & 46.4 & 323.7 & 378.7 & 249.6 & 42.1 & 42.3 & 45.1 & 43.2 \\
\hline $\mathrm{T}_{6}-100 \% \mathrm{NP}+25 \% \mathrm{~K}+15 \mathrm{tha}^{-1} \mathrm{RHA}$ & 41.4 & 316.6 & 396.0 & 251.3 & 42.2 & 40.8 & 40.6 & 41.2 \\
\hline $\mathrm{T}_{7}-100 \% \mathrm{NP}+20 \mathrm{t} \mathrm{ha}^{-1} \mathrm{RHA}$ & 39.1 & 263.1 & 292.2 & 196.9 & 42.8 & 39.9 & 40.4 & 41.0 \\
\hline $\begin{array}{c}\text { Mean } \\
\end{array}$ & 41.3 & 277.7 & 333.4 & & 39.9 & 41.2 & 43.9 & \\
\hline SEd & 2.20 & 15.57 & 25.58 & & 1.73 & 1.14 & 1.17 & \\
\hline $\mathrm{CD}(\mathrm{p}=0.05)$ & 4.72 & 33.40 & 54.86 & & 3.71 & 2.44 & 2.51 & \\
\hline
\end{tabular}

Table.2 Effect of treatments on plant height and root and shoot parameters and total dry matter of maize

\begin{tabular}{|c|}
\hline Treatments \\
\hline $\mathrm{T}_{1}$ - Absolute control \\
\hline $\mathrm{T}_{2}-100 \% \mathrm{NPK}$ \\
\hline $\mathrm{T}_{3}-100 \% \mathrm{NPK}+5 \mathrm{t} \mathrm{ha}^{-1}$ RHA \\
\hline $\mathrm{T}_{4-100 \% \mathrm{NP}+75 \% \mathrm{~K}+5 \mathrm{tha}^{-1} \mathrm{RHA}}$ \\
\hline $\mathrm{T}_{5}-100 \% \mathrm{NP}+50 \% \mathrm{~K}+10 \mathrm{tha}^{-1} \mathrm{RHA}$ \\
\hline $\mathrm{T}_{6}-100 \% \mathrm{NP}+25 \% \mathrm{~K}+15 \mathrm{tha}^{-1} \mathrm{RHA}$ \\
\hline $\mathrm{T}_{7}-100 \% \mathrm{NP}+20 \mathrm{t} \mathrm{ha}^{-1} \mathrm{RHA}$ \\
\hline $\begin{array}{c}\text { Mean } \\
\end{array}$ \\
\hline SEd \\
\hline $\mathrm{CD}(\mathrm{p}=0.05)$ \\
\hline
\end{tabular}

Plant height (cm) at days after sowing

\begin{tabular}{|c|c|c|c|c|c|c|c|c|c|}
\hline $\mathbf{1 5}$ & $\mathbf{3 0}$ & $\mathbf{4 5}$ & Mean & $\begin{array}{c}\text { Shoot } \\
\text { weight } \mathbf{( g )}\end{array}$ & $\begin{array}{c}\text { Root } \\
\text { weight } \mathbf{( g )}\end{array}$ & $\begin{array}{c}\text { Total Dry } \\
\text { matter } \mathbf{( g )}\end{array}$ & $\begin{array}{c}\text { Root } \\
\text { length } \mathbf{( c m )}\end{array}$ & $\begin{array}{c}\text { Root } \\
\text { volume } \mathbf{( c m}^{\mathbf{3}} \mathbf{)}\end{array}$ & $\begin{array}{c}\text { Shoot/ } \\
\text { Root ratio }\end{array}$ \\
\hline 29.3 & 65.4 & 72.5 & $\mathbf{5 5 . 8}$ & 5.6 & 1.66 & 7.9 & 28.0 & 4.7 & 3.40 \\
\hline 32.0 & 85.1 & 94.8 & $\mathbf{7 0 . 6}$ & 11.8 & 2.13 & 13.9 & 33.5 & 10.7 & 5.54 \\
\hline 32.4 & 89.7 & 95.5 & $\mathbf{7 2 . 5}$ & 12.5 & 3.14 & 15.6 & 36.8 & 11.3 & 3.98 \\
\hline 32.7 & 91.2 & 96.3 & $\mathbf{7 3 . 4}$ & 13.6 & 3.49 & 17.1 & 37.2 & 12.0 & 3.89 \\
\hline 34.7 & 92.3 & 102.8 & $\mathbf{7 6 . 6}$ & 13.8 & 3.57 & 17.3 & 43.0 & 14.0 & 3.85 \\
\hline 31.6 & 91.7 & 94.0 & $\mathbf{7 2 . 4}$ & 12.1 & 3.18 & 14.6 & 42.2 & 10.0 & 3.79 \\
\hline 30.5 & 81.3 & 84.0 & $\mathbf{6 5 . 3}$ & 10.0 & 2.89 & 12.5 & 37.3 & 7.3 & 3.46 \\
\hline $\mathbf{3 1 . 9}$ & $\mathbf{8 5 . 2}$ & $\mathbf{9 1 . 4}$ & & $\mathbf{1 1 . 3}$ & $\mathbf{2 . 8 6}$ & $\mathbf{1 4 . 1}$ & $\mathbf{3 6 . 9}$ & $\mathbf{1 0 . 0}$ & $\mathbf{4 . 0 0}$ \\
\hline 0.77 & 2.22 & 4.60 & & 0.82 & 0.16 & 0.88 & 2.29 & 0.59 & 0.42 \\
\hline 1.65 & 4.76 & 9.87 & & 1.77 & 0.34 & 1.88 & 4.92 & 1.27 & 0.90 \\
\hline
\end{tabular}


The lowest value was recorded in absolute control. Leaf chlorophyll content was enhanced with the application of rice husk biochar to spinach (Milla et al., 2013).

\section{Plant height}

The plant height on 15 DAS varied from 29.3 and $34.7 \mathrm{~cm}$. The highest plant height $(34.7$ $\mathrm{cm}$ ) was observed in the treatment with $100 \%$ $\mathrm{NP}+50 \% \mathrm{~K}+10 \mathrm{t} \mathrm{ha}^{-1} \mathrm{RHA}$. The treatment $\mathrm{T}_{5}-100 \% \mathrm{NP}+50 \% \mathrm{~K}+10 \mathrm{t} \mathrm{ha}^{-1} \mathrm{RHA}$ significantly differ from others and found to be on par. The lowest value was recorded in absolute control.

On $30^{\text {th }}$ day, the plant height varied from 65.4 to $92.3 \mathrm{~cm}$. The maximum value $(92.3 \mathrm{~cm})$ was observed in the treatment with $100 \% \mathrm{NP}$ $+50 \% \mathrm{~K}+10 \mathrm{t} \mathrm{ha}^{-1} \mathrm{RHA}$. The treatments $\mathrm{T}_{3}-$ $100 \% \mathrm{NPK}+5 \mathrm{t} \mathrm{ha}^{-1}$ RHA, $\mathrm{T}_{4}-100 \% \mathrm{NP}+$ $75 \% \mathrm{~K}+5 \mathrm{t} \mathrm{ha}^{-1} \mathrm{RHA}, \mathrm{T}_{5}-100 \% \mathrm{NP}+50 \%$ $\mathrm{K}+10 \mathrm{t} \mathrm{ha}^{-1} \mathrm{RHA}$ and $\mathrm{T}_{6}-100 \% \mathrm{NP}+25 \%$ $\mathrm{K}+15 \mathrm{t} \mathrm{ha}^{-1}$ RHA significantly differ from others and found to be on par. The lowest value was recorded in absolute control.

The plant height on 45 DAS varied from 72.5 and $102.8 \mathrm{~cm}$. The highest plant height $(102.8$ $\mathrm{cm}$ ) was observed in the treatment with $100 \%$ $\mathrm{NP}+50 \% \mathrm{~K}+10 \mathrm{t} \mathrm{ha}^{-1}$ RHA. The treatments $\mathrm{T}_{2}-100 \% \mathrm{NPK}, \mathrm{T}_{3}-100 \% \mathrm{NPK}+5 \mathrm{tha}^{-1}$ RHA, $\mathrm{T}_{4}-100 \% \mathrm{NP}+75 \% \mathrm{~K}+5 \mathrm{tha}^{1} \mathrm{RHA}$, $\mathrm{T}_{5}-100 \% \mathrm{NP}+50 \% \mathrm{~K}+10 \mathrm{tha}^{-1} \mathrm{RHA}$ and $\mathrm{T}_{6}-100 \% \mathrm{NP}+25 \% \mathrm{~K}+15 \mathrm{t} \mathrm{ha}^{-1} \mathrm{RHA}$ significantly differ from others and found to be on par. The lowest value was recorded in absolute control.

The mean value of plant height varied from 55.8 and $76.6 \mathrm{~cm}$. The maximum mean plant height $(76.6 \mathrm{~cm})$ was observed in the treatment with $100 \% \mathrm{NP}+50 \% \mathrm{~K}+10 \mathrm{t} \mathrm{ha}^{-1}$ RHA. The treatments $\mathrm{T}_{3}-100 \% \mathrm{NPK}+5 \mathrm{t}$ $\mathrm{ha}^{-1}$ RHA, $\mathrm{T}_{4}-100 \% \mathrm{NP}+75 \% \mathrm{~K}+5 \mathrm{tha}^{-1}$ RHA, T $_{5}-100 \% \mathrm{NP}+50 \% \mathrm{~K}+10 \mathrm{t} \mathrm{ha}^{-1}$ RHA and $\mathrm{T}_{6}-100 \% \mathrm{NP}+25 \% \mathrm{~K}+15 \mathrm{tha}^{-1} \mathrm{RHA}$ significantly differ from others and found to be on par. The lowest value was recorded in absolute control.

Fawzy et al., (2005) showed that potassium fertilizer had a significant effect on the fresh weights of leaves and stems, early and total yield of sweet pepper plants. This result is supported by Chen et al., (1996) on eggplant and Al-Karaki (2000) and Gupta and Sengar (2000) on tomato plant who mentioned that increasing vegetative growth is due to increasing potassium fertilizer levels. Along with potassium RHA could have supplied sufficient $\mathrm{Si}$ to maize crop. The RHA application to rice nurseries seems to be an efficient way of recycling plant $\mathrm{Si}$ and have agronomic and environmental benefits, especially in developing countries (Sistani et al., 1997).

\section{Shoot and root parameters}

The shoot weight varied from 6.3 and $13.8 \mathrm{~g}$. The highest shoot weight (13.8g) was observed in the treatment with $100 \% \mathrm{NP}+$ $50 \% \mathrm{~K}+10 \mathrm{t} \mathrm{ha}^{-1} \mathrm{RHA}$. The treatments $\mathrm{T}_{3}-$ $100 \% \mathrm{NPK}+5 \mathrm{t} \mathrm{ha}^{-1} \mathrm{RHA}, \mathrm{T}_{4}-100 \% \mathrm{NP}+$ $75 \% \mathrm{~K}+5 \mathrm{t} \mathrm{ha}^{-1} \mathrm{RHA}$ and $\mathrm{T}_{5}-100 \% \mathrm{NP}+$ $50 \% \mathrm{~K}+10 \mathrm{t} \mathrm{ha}^{-1}$ RHA significantly differ from others and found to be on par. The lowest value was recorded in absolute control.

The root weight varied from $1.56 \mathrm{~g}$ and 3.57 g. The highest root weight $(3.57 \mathrm{~g})$ was observed in the treatment with $100 \% \mathrm{NP}+$ $50 \% \mathrm{~K}+10 \mathrm{t} \mathrm{ha}^{-1}$ RHA. The treatments $\mathrm{T}_{4}-$ $100 \% \mathrm{NP}+75 \% \mathrm{~K}+5 \mathrm{t} \mathrm{ha}^{-1} \mathrm{RHA}$ and $\mathrm{T}_{5-}$ $100 \% \mathrm{NP}+50 \% \mathrm{~K}+10 \mathrm{t} \mathrm{ha}^{-1}$ RHA significantly differ from others and found to be on par. The lowest value was recorded in absolute control.

The total dry matter varied from 7.9 and 17.3g. The highest total dry matter (17.3 g) 
was observed in the treatment with $100 \%$ $\mathrm{NP}+50 \% \mathrm{~K}+10 \mathrm{t} \mathrm{ha}^{-1} \mathrm{RHA}$. The treatments $\mathrm{T}_{3}-100 \% \mathrm{NPK}+5 \mathrm{t} \mathrm{ha}^{-1}$ RHA, $\mathrm{T}_{4}-100 \%$ $\mathrm{NP}+75 \% \mathrm{~K}+5 \mathrm{t} \mathrm{ha}^{-1} \mathrm{RHA}$ and $\mathrm{T}_{5}-100 \%$ $\mathrm{NP}+50 \% \mathrm{~K}+10 \mathrm{t} \mathrm{ha}^{-1}$ RHA significantly differ from others and found to be on par. The lowest value was recorded in absolute control.

The root length varied from 28.0 and $43.0 \mathrm{~cm}$. The highest root length $(43.0 \mathrm{~cm})$ was observed in the treatment with $100 \% \mathrm{NP}+$ $50 \% \mathrm{~K}+10 \mathrm{t} \mathrm{ha}^{-1} \mathrm{RHA}$. The treatments $\mathrm{T}_{5}$ $100 \% \mathrm{NP}+50 \% \mathrm{~K}+10 \mathrm{t} \mathrm{ha}^{-1} \mathrm{RHA}$ and $\mathrm{T}_{6}-$ $100 \% \mathrm{NP}+25 \% \mathrm{~K}+15 \mathrm{t} \mathrm{ha}^{-1} \mathrm{RHA}$ significantly differ from others and found to be on par. The lowest value was recorded in absolute control.

The root volume varied from 4.7 and $14.0 \mathrm{~cm}$. The highest root volume $(14.0 \mathrm{~cm})$ was observed in the treatment with $100 \% \mathrm{NP}+$ $50 \% \mathrm{~K}+10 \mathrm{t} \mathrm{ha}^{-1} \mathrm{RHA}$. The treatment $\mathrm{T}_{5}-$ $100 \% \mathrm{NP}+50 \% \mathrm{~K}+10 \mathrm{t} \mathrm{ha}^{-1} \mathrm{RHA}$ significantly differ from others and found to be on par. The lowest value was recorded in absolute control (Table 2).

The shoot to root ratio varied from 3.40 and 5.54. The highest shoot root ratio (5.54) was observed in the treatment with $100 \%$ NPK. The treatment $\mathrm{T}_{2}-100 \%$ NPK significantly differ from others and found to be on par. The lowest value was recorded in absolute control.

The simulative effect may be due to the role of potassium on production of enzyme activity and enhanced translocation of assimilative and photosynthesis (El-Desuki et al., 2006). Similar results were recorded in cowpea (Priyadharshini et al., 2009) and wheat (Thind et al., 2012). Onwudite et al., (2015) have also demonstrated that ashes of agro-wastes increase crop yield.

Rice husk ash found to be used in combination along with inorganic fertilizers to enhance crop production. It can enhance nutrient availability and can affect the hydrophysical properties. In the present study, it was observed that application of RHA in combination $\mathrm{N}$ and $\mathrm{P}$ fertilizer enhances chlorophyll content, plant height, shoot weight, root length, root weight, root volume and total dry matter content of maize. It can be concluded that substituting rice husk ash @ $10 \mathrm{t} \mathrm{ha}^{-1}$ along with $50 \%$ of recommended $\mathrm{K}$ can enhance maize growth.

\section{References}

Abukari, A. 2014. Effect of rice husk biochar on maize productivity in the guinea savannah zone of Ghana. A Thesis Submitted to the Department of Agroforestry, Kwame Nkrumah University of Science and Technology in partial fulfilment of the requirements for the degree of M.Sc. Faculty of Renewable Natural Resources, College of Agriculture and Renewable Natural Resources, Ghana.pp103.

Al-Karaki, G. N. 2000. Growth, sodium, and potassium uptake and translocation in salt stressed tomato. Journal of Plant Nutrition, 23(3): 369-379.

Chen Zhen De, Huang Jun Jie and CaiKui.1996. Studies on fertilizer application levels of seedling stage of eggplant raised with mixed media. China Vegetables, 4:16-18.

EL-Desuki M, M. M. Abdel-Mouty and A. H. Ali.2006. Response of Onion Plants to Aditional Dose of Potassium Application. J. Applied Science Res., 2(9): 592-597.

Fawzy, Z. F., A. G. Behairy and S. A. Shehata.2005. Effect of potassium fertilizer on growth and yield of sweet pepper plants (Capsicum annuum, L.) Egypt J. of Agriculture Res., 2(2): 599610.

Goncalves M.R.F. 2007. Thermal insulators made with rice husk ashes: Production and correlation between properties and microstructure. Construction and Building Materials 21: 2059-2065. 
Gupta, C. R. and S. S. Sengar.2000. Response of tomato (Lycopersicon esculentum Mill.) to nitrogen and potassium fertilization in acidic soil of Bastar. Vegetable Sci. 27(1): 94-95.

Humphries, E. S. 1956. Mineralogical composition and ash analysis. Modern methods of plant analysis. Springer Verlag. Berlin. 1: 468-502.

Jackson, M.L. 1973. Soil chemical analysis. Prentice Hall of India Private Limited, New Delhi. p.496.

Milla, O.V, Rivera1, E.B., Huang, W.J., Chien, C.C, Wang, Y.M. 2013. Agronomic properties and characterization of rice husk and wood biochars and their effect on the growth of water spinach in a field test. J. Soil Sci. and Plant Nutrition, 13 (2): 251-266.

Minolta, C. 1989. Manual for Chlorophyll meter SPAD-502. Minolta Cameraco, Osaka, Japan.

Muntohar, A.S 2002. Utilization of uncontrolled burnt rice husk ash in soil improvement. Dimensiteknik Sipil, 4 (2): 100 - 105.

Nwite, J.C., Igwe, C.A., Obalum, S.E.2011. The Contributions of Different Ash Sources to the Improvement in Properties of a Degraded Ultisol and Maize Production in Southeastern Nigeria. AmericanEurasian J. of Sustainable. Agriculture: 34-41

Olsen, S.R., C.V. Cole, F.S. Watanabe and A.L. Dean. 1954. Estimation of available phosphorus in soil by extraction with sodium bicarbonate. USDA Circ. 939.

Onwudike, S.U., Asawalam, D.O., Ano, A.O.2015. Comparative Evaluation of Burnt and Unburnt Agro-wastes on Soil Properties and Growth Performance of
Cocoyam in a Humid Environment. Asian J. of Agricultural Res. 9 (6): 276-292.

Priyadharshini, J. and Seran, T.H. 2009. Paddy husk ash as a source of potassium for growth and yield of cowpea (Vigna unguiculata). J. Agricultural Sci. 4 (2):6776.

Singh, A., R.K. Gupta, Y. Singh, H.S. Thind, B. Singh, and V. Singh. 2013. Effect of Rice Husk Ash and Bagasse Ash on Inorganic Phosphorus Fractions and Available Phosphorus in an Alkaline Soil under Rice (Oryza sativa L.)-Wheat (Triticum aestivum L.) Cropping System. J. Indian Soc. of Soil Sci. 61(3): 258-260.

Sistani, K.R, N.K. Savant, K.C. Reddy. 1997. Effect of rice hull ash silicon on rice seedling growth. J. Plant Nutrition, 20(1): 195-201

Stanford, S. and L.English.1949.Use of flame photometer in rapid soil tests of $\mathrm{K}$ and Ca. Agron. J., 41: 446-447.

Subbiah, B.V. and C.L. Asija.1956. A rapid procedure for estimation of available nitrogen in soils. Curr.Sci., 25: 259-260.

Tan, K.H. 1998. Soil sampling, preparation and analysis. p. 133-134.

Thind, H.S., Yadvinder Singh, Sandeep Sharma, Varinderpal Singh.2016. Phosphorus fertilizing potential of bagasse ash and rice husk ash in wheatrice system on alkaline loamy sand soil. J. of Agricultural Sci. 155(3):465-474

Toth, S. J. and A.L. Prince. 1949. Estimation of cation exchange capacity and exchangeable calcium, potassium and sodium contents of soils by flame photo meter technique. Soil Sci., 67: 439-445.

\section{How to cite this article:}

Saranya, P., C.M. Sri Gayathiri and Sellamuthu, K.M. 2018. Potential Use of Rice Husk Ash for Enhancing Growth of Maize (Zea mays). Int.J.Curr.Microbiol.App.Sci. 7(03): 899-906. doi: https://doi.org/10.20546/ijcmas.2018.703.105 